\title{
Hearing loss in osteogenesis imperfecta patients
}

\author{
Lai Thu Ha ${ }^{1 *}$, Vu Chi Dung², Can Thi Bich Ngoc ${ }^{2}$, Bui Phuong Thao², Nguyen Ngoc Khanh², Luong Hong Chau ${ }^{3}$ \\ From 8th APPES Biennial Scientific Meeting \\ Darwin, Australia. 29 October - 1 November 2014
}

Osteogenesis imperfecta (OI) is an inherited bone and connective tissue disorder associated with the lifelong occurrence of frequent fractures following even mild trauma. Hearing loss is frequently reported in patients with OI. Objective: to examine the ratio of hearing loss in children with OI, and the relationship between audiological findings and CT images of temporal bone in children with OI. Subject and methods: forty - two children aged 5 to 17 years with OI were included in the study. The patients have type A of tympano and were mesured thresold of hearing by play audiometry. CT imaging was performed in 8 cases as well. Imaging abnormalities were correlated with clinical phenotypes and severity of hearing loss deduced from audiograms. Results: Hearing loss of all etiologies was observed in $28.05 \%$ of ears in studied OI patients. Sensorineural and mixed hearing loss was observed in $4.88 \%$ and conductive hearing loss was detected in $23.17 \%$ of ears. CT revealed bone bridge image in the middle ear (10/16 ears), hypodense foci in the fissula ante fenestram (4/16 ears) and cochlear (2/16 ears), abnormal stape ( $5 / 16$ ears). Conclusions: hearing loss in children with osteogenesis imperfecta is quite frequent. We have all type of hearing loss, but the conductive of hearing loss have highest ratio. The site of abnormal on temporal bone CT images in OI corresponds to presence and type of hearing loss determined by audiometry.

\footnotetext{
Authors' details

'Otolaryngology department, National Hospital of Pediatrics, Hanoi, Vietnam. ${ }^{2}$ Department of Endocrinology, Metabolism and Genetics, National Hospital of Pediatrics, Hanoi, Vietnam. ${ }^{3}$ Ear Department, Ear - Nose - Throat National Hospital, Hanoi, Vietnam.
}

Published: 28 April 2015

'Otolaryngology department, National Hospital of Pediatrics, Hanoi, Vietnam Full list of author information is available at the end of the article
doi:10.1186/1687-9856-2015-S1-P68

Cite this article as: Ha et al:: Hearing loss in osteogenesis imperfecta patients. International Journal of Pediatric Endocrinology 20152015 (Suppl 1):P68.
Submit your next manuscript to BioMed Central and take full advantage of:

- Convenient online submission

- Thorough peer review

- No space constraints or color figure charges

- Immediate publication on acceptance

- Inclusion in PubMed, CAS, Scopus and Google Scholar

- Research which is freely available for redistribution
() Biomed Central

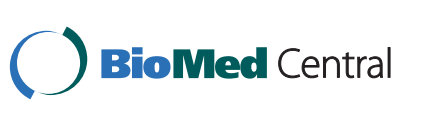

(c) $2015 \mathrm{Ha}$ et al; licensee BioMed Central Ltd. This is an Open Access article distributed under the terms of the Creative Commons Attribution License (http://creativecommons.org/licenses/by/4.0), which permits unrestricted use, distribution, and reproduction in any medium, provided the original work is properly cited. The Creative Commons Public Domain Dedication waiver (http:// creativecommons.org/publicdomain/zero/1.0/) applies to the data made available in this article, unless otherwise stated. 